\title{
天下の公 器
}

永井彰一郎

大日本篣業協會雜誌は號を重ねるごとた愈々立派になり皆々樣の御盡力の程會員として此の上なくよろこば しく感謝の至に存じ率り候、夫れにつけても英交抄譯がなく海外には少しも知れぬ有樣は誠に殘念にて先日も アイテル敎授にお見:せ致したるに四十年の歷史を有し拄酸監工業全般を網羅する世界に類例のない新誌なるこ

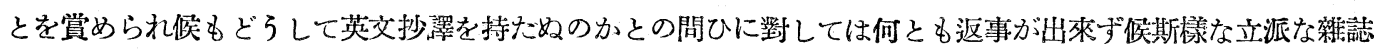

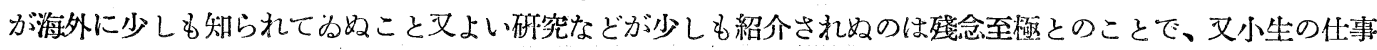

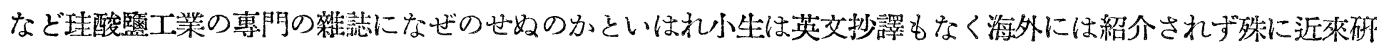
究報告が退けられて歡迎されない有樣で歡迎されるのは平易な講義漫談的のもので小生も獨逸其の他の喜業の つまらぬ記事をのせてるるといふ返事しか出來なかりしを誠に残念に存じ居り候。

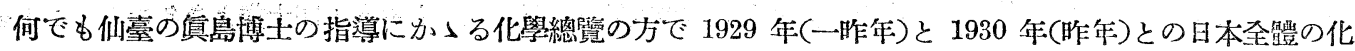
學、化學工業全體の雜誌印刷物の賁數を總計して昨年は一䝫年より $30 \%$ 方減退してるる由で之は全く民政黨 の消極政策の賜物だとのことを諭ぜられ居り候由、然るに大日本筧業協會にては 1930 年(咋年)の1月-10月 の10册と本年1931年1月一-10月の10册をを比較すると698 頁から 726 頁に寧ろ增加し更に去年は 9 ポであつ たすのが本年は 8 ホになつて1頁に 30 -40\% 方多く大るやうになつて侗且つこの樰加は䆬に $30 \%$ 以上の增 加意味して他の一般に逆行して大發展の模樣は全く編輯各位の御努力に依ること〉梁く梁く喜び申し侯。然 し其の內容は必ずしも之に本行せず前述申し候如く政究報告的のものは次第に退けられ講義、資粼、漫錄的の

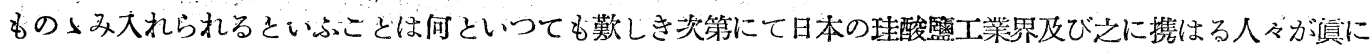
この有樣なので山るか、一部有力な人の頭がその樣で一般がもつと淮んでるるのにも拘らず自己の㽬分ら割り 出したま〉を其の權力で逐行させせる樣な結果にあらざるか、此の點は餘程愼重に考慮して指導機關たる大切な る雜誌としては一般を淮めるのも退步させるのも一に此の雜誌の力かと思ふと仲々重大問題と考へられ候。

近く11月9日(獨逸窵業學會)、10日(カイザーウイルヘルムイシスチチユート珪酸監研究部後援會) $11,12,13$ 日

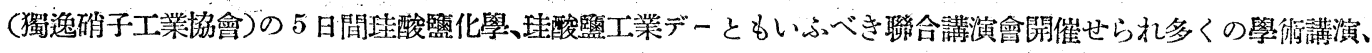
研究報告、工場刑究試驗などが發表され小生ども此の上なくよろこび居り候、京大吉岡氏、仲年氏も參加され、小 林作本氏も英或より間に合ふやう參り得るかと存じ居り候っ右の如く獨逸珪酸工業に關する學會協會は誠に歷 史淺きむ極めて學術的に進まんとし四十年の長き歴史の我が大日本窵業協會が近來特に早やくも老ぼれて通俗 化平易化の退化は全く老ぼれた一部有力者の意のま〉になりつつもるのではなかららか天下の公器、我が珪酸

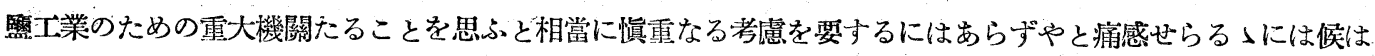

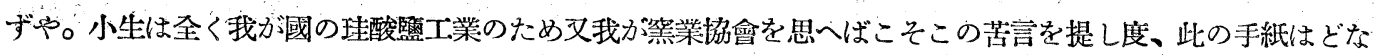
たに挸せ下されてもよろしく全く小生は終始一貫我黨業協會のためを切䆬に思へばこそ繰り返し此の苦言を 呈し樑慮を煩はし度き次第に御座候。

\section{研究に 就 て}

熊澤 治 郎 吉

研究とは何ぞや、各事業每に硎究の必要なるは今更いふ迄もないが、今製造業に就て試质に說明して見れば 
大抵の人の研究觀といいば、郎ち技術上の㸴究の久を指摘する樣であるが、實際は然るるのではなくて、小子

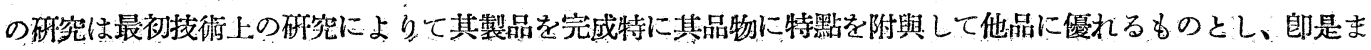
でが技術上の朔究であるが小子は更に其製品を販賣して全部を現金に交換し終るまでが所謂㸴究の範圍に屬す

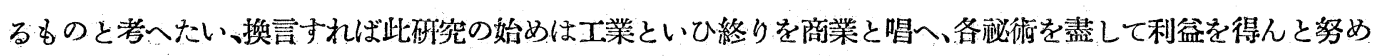
て居るが、更に此兩法の外に行政聽の命令により賽行して居る所の矿究がある事を忘れてはならぬ、否寧ろ此 最後の方法で利する事は所謂工業並に商業の何れより得らる」利䀂よりも遥に大なるものである事が往々ある 工辣兩者に就ての說明は殆ど何人もよく知らるっ所であるから暫く之を省き最後の方法に就て其數例を列擧し 說明を加へて見れば次の通りである、小子は此方法を工業政策といひま゙すが、其大略の二三を說明して見れば

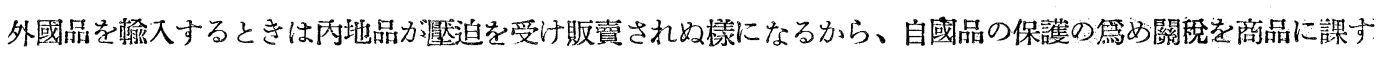
るが如き、或る品物を安く整造せんが篇め原料又は燃料を渾搬するとき、或は製品を安く運搬する䉆め、其距 離の遠近に應じて其運顀の補助を行ふが如き、或は製品の價格を維持するが䉆め組合團賗を組織し其組合內の ものは凡て一定價格によらざれば販賣せざる事を協定するが如き、或は甲の製造洗に特權を與へ濫に乙其他の ものは甲の品を製造せしめざるが如き、或は特許法によりて或期限內は何人も其製造法を犯す事能はざるが如 き、等何れも前述の兩法外の事項で然かも有効、有利な方法であるから是亦小子の所謂湖究中に加ふべきもの であると信ずる。以上の是等三方泆共同時に同碌に本行して研究を重ね、然かも三者を合して一團體となし經

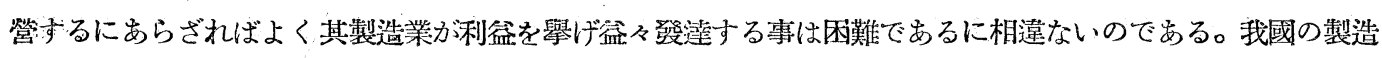

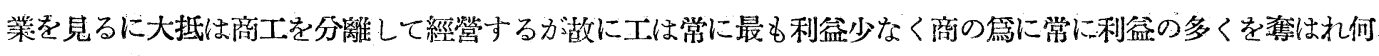

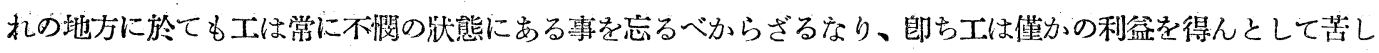
めるに反し、商は資本を投ずる事ありとはいい、工の利益よりも遥に大なるものを得るに然も甚易々たるが敌 きものありといふて過言でない事と信ずる、其實例としても商業地は繁昌し工業地は非常に振はざるは何人も 承知される事と思ふ、夫故に多少考へのある製造家は常に商を策業とし、否寧ろ工を三分、商に七分の力を盡 して經營して居るものは常に其工場が安全で工で損をしても商に於て利したる所によりて之を補ひ居る事は制 然して居る、陶磁器業に關する大工場が郎ち其實現したものであるが、他の小工場が其追從を許さぬのは郎ち 資本の點に於て及ば嬀め致方もないが、是非共各工場共其方洗で進みたいのである、更に更に第三の工業政 策としては獨國の如き工業立國論より立脚せる方法によれるに見柏ふて適當なる政策か現はるつに於ては一層 斯業の發展が出來ると信ずる。次には順を遍ふて工、商並に工業政策に就て其詳細なる說明をなし所謂其方面 の研究の事を沭ぶべきのが本意なれど裂むべし筆者は元來が工業技術者專門なる立場にあるが故に今は唯工に 就てのみ所感を述ぶるの自由あるのみなるを如何せん、故に他日誰か商並に工業改策に就ても更に梁き政究說 明を與一られん事を希望すると同時に、若し是等の事を說明さるつならば此不景氣時に於ける事業展開策とし 七大に頌者の參考に資する所もあると信ずるものである。

見よ我國に於ける康指の大會社は既に前述せし通り常に此要素の三項を合體して經營し居るが䉆め、他の中 小工場又は會社に比して、常に有利なる位置にあるや明かにして、諸外國に於ての製造業亦常に茲に着眼して實 施しつ১あるに反し、我國民性として團結心は實戰時のみに特に發揮し本時の戰争たる實業界に於ては全く實 現嚾にして、大抵は小規模にても個人の經營を貴ぶの風替むるは最も其短所とする所である、其結果として數人 團結して會社を經營する事少なき篇め、自然に小規模なる商工業が备獨竞の經營を行ふもの多きを見る次第て 
ある事は明かなる事實である。

さて本問の工業に關する䃌究に就て考ふるに之を二種に區別する事となる、其一は學問上に基礎を置き、如何 なる事實でもよいから斯樣な事を行へば其結果として斯くなるものであるといら數多の研究結果を成るべく多 數に發表するといふ研究である此方は其結果が工業用となるべきや否を考ふる必要なく唯漫然として幾多の事 實を列擧するのである。他の一は前記の事實を基礎として斯る方法を用ふるときは之を工業用に應用する事が 出來るといふ㰬論經濟的に換算する事も可能なる事實に限定せらる〉砰究である。

上記兩種の研究中、前記のものは各種の大學、高等工業學校其他理化學砛究所等で實驗するもので其外の政 究所等は此種の砸究をなすべきものでないと同時に叙上の場所では酒を翼造販賣し其他眼鏡、印材、藥品等を 同じく製造販賣すべき所でない。

又上記中の後段の應用を主とする研究は政府立又は地方聽立各種の工業試驗場或は研究所等で行ふべきもの で、自然に其間に區別あるべきものであると同時に是等の砄究所では理論的の跨究を避け化學式を作製するに 努力するが如き週期率を考ふるが如き、或は大學の卒業論交又は其他の理論を報告するが如き等の事なく、荷 も此方法を以てせば何々工業の如何なる場合には應用し得、然かも其經濟的の計算に於ては斯る打算を見出し

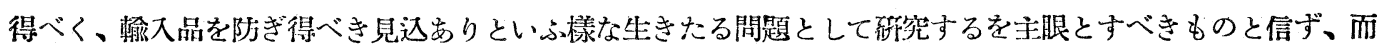
して縱令其砄究は簡單でも其頁數は眇くとも其工業的傮值あるものを䂙究すべきである。

更に各種工業試驗場又は政究所と各工場に附屬する政究とも自ら異る所あり、前者は一般に共通する事項に 就て努めて研究報告し、後者は特殊の默に就て更に調查し他の工場又は其他のにては絕體に模做し能はざるも

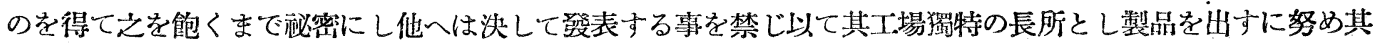
特色によりては沠して他工場で如何にするも製し能はざらしむる事とする樣にし、大抵の場合に於て其工場の 縱覽をも謝絕するのが寧ろ逗當なる力泆であると信ずるものである。

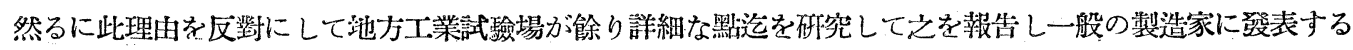
に至らば却て其特長とすべき所は何人にも知れ渡り折角の骨折も其效少なく一般に安賣せざる可からざるに至 るべし、若し斯樣なる場合に刅て甲には發表してに秘するが如き事あらんか忽ち其技術者が排斥せらる〉樣な 運命に至るやも知れしぬものである。故に池方並に中央工業試驗所の仕事は前述の如く努めて一般に屬する事の みを研究發表するに止め、各工場に於ては其方法を基礎として更に進む可き加と考へらる。

終りに一言したき事は地方工業學校卒業者が努めて都會地に進出せんとし又其學校の當事者も其就職口を都 會に求めんとて、每年旅費を出して職員を都會の地に出張せしむるが如き亦大に注意すべきにはあらずや、元來 或地方に設立せる工業學校の程度は其地方の工業に適する學課科程を課し居るを以て、卒業後は其地方に在職 するのが至當である、否其卒業生が其池方に在職して始めて適當なる椭究が進めらるつのである、小子も今日 まで各地の工業學校卒業生を使用し寛地に試みたる經驗によれば最有效にして、正に適當なる其地方の改善者 とするに足るものと信じて疑はぬものである。願くは地方工業學校卒業生諸氏の努力により現在の日本工業改 善の緒につく樣に致したい、小子年老いたりと踓侗地方の工業改善には上記の諸氏に希ふ所甚多く且老いたる 身を提げて以て各卒業生と共に努力せんとする勇氣は滿々たるものである事を茲に擱筆と共に 希望するもの である。

甚勝手な事を述べ讀者中には御立腹の方々もあるかと思はざるにはあらざるも所謂小子の所感を遠慮なく述 べた、然し最早之を再びせざる事を御承知ありたい。 